\title{
PENERAPAN MODEL PEMBELAJARAN KOOPERATIF TIPE NUMBER HEAD TOGETHER (NHT) UNTUK MENINGKATKAN HASIL BELAJAR EKONOMI SISWA KELAS XI IS SMA N 1 SINGARAJA KABUPATEN BULELENG PADA SEMESTER GANJIL TAHUN PELAJARAN 2013/ 2014
}

\author{
Agus Dita Saputra \\ SMA Diyatmika Denpasar \\ Denpasar, Indonesia \\ e-mail: agusditasaputra@yahoo.com
}

\begin{abstract}
Abstrak
Penelitian tindakan kelas ini bertujuan untuk mengetahui hasil belajar siswa setelah diterapkannya model pembelajaran kooperatif tipe Numbered Head Together (NHT) pada siswa kelas XI IS SMA Negeri 1 Singaraja tahun pelajaran 2013/2014. Penelitian ini akan dilaksanakan dalam pola siklus. Artinya siklus selanjutnya akan ditentukan berdasarkan siklus sebelumnya, sampai diperoleh hasil yang diharapkan. Penelitian ini direncanakan akan dilaksanakan dalam beberapa siklus, tiap siklus akan dilaksanakan sebanyak empat kali pertemuan. Pertemuan pertama, kedua, dan ke tiga untuk pembahasan materi, sedangkan pertemuan ke empat untuk pemberian tes evaluasi dan refleksi.

Berdasarkan hasil penelitian menunjukan bahwa model pembelajaran kooperatif tipe Number Head Together (NHT) dapat meningkatkan hasil belajar ekonomi siswa kelas XI IS SMA N 1 Singaraja pada semester ganjil tahun pelajaran 2013/2014. Hal ini dapat dilihat dari nilai rata-rata hasil belajar ekonomi yaitu Pada siklus I ketuntasan belajar siswa hanya mencapai $33,33 \%$ dengan rata-rata hasil belajar siswa sebesar 67,22, sedangkan pada siklus II ketuntasan belajar siswa sudah mencapai $91,70 \%$ rata-rata hasil belajar siswa sebesar 90,22. Dari siklus I hingga siklus II ketuntasan belajar siswa mengalami peningkatan sebesar $58,37 \%$.
\end{abstract}

Kata kunci: Kooperatif, Numbered Head Together (NHT)

Abstract

Classroom action research aims to determine student learning outcomes after the implementation of cooperative learning model Numbered Head Together (NHT) in class XI IS SMAN 1 Singaraja school year 2013/2014. This research will be conducted in a cycle pattern. This means that the next cycle will be determined based on the previous cycle, until the desired result was obtained. This research is planned to be carried out in some cycles, each cycle will be held four meetings. The first meeting, second, and third for a discussion of the material, while the fourth meeting for the provision of test evaluation and reflection.

Based on the results of the research show that the cooperative learning model Number Head Together (NHT) to improve learning outcomes of students in class XI economics IS SMA N 1 Singaraja in the first semester of school year 2013/2014. It can be seen from the average value of the results of the economic study is the first cycle of mastery learning students only reaches $33.33 \%$ with an average of 67.22 students 'learning outcomes, while the second cycle students' mastery learning has reached $91.70 \%$ an average of 90.22 students' learning outcomes. From the first cycle to the second cycle of mastery learning students has increased by $58.37 \%$.

Keywords: Cooperative, Numbered Head Together (NHT)

\section{PENDAHULUAN}

Pembangunan di bidang pendidikan sebagai salah satu bagian dari pembangunan nasional, perlu diwujudkan guna peningkatan dan kemajuan sektor pendidikan. Oleh karena itu pemerintah berupaya semaksimal mungkin

mengadakan perbaikan $r$ dan
penyempurnaan di bidang pendidikan.
Sebagai langkah antisipasi, maka
pendidikan banyak diarahkan pada
penataan proses belajar. Hal tersebut
dimaksudkan untuk pencapaian hasil
belajar semaksimal mungkin.

Agus Dita Saputra | 40 
Pelajaran ekonomi adalah salah satu mata pelajaran yang berusaha membekali wawasan dan keterampilan siswa untuk mampu beradaptasi dan bermasyarakat serta menyesuaikan dengan perkembangan dalam era globalisasi. Pelajaran ekonomi difokuskan pada fenomena empirik ekonomi yang ada di sekitar lingkungan siswa sehingga siswa dapat merekam fenomena ekonomi yang ada di sekitar lingkungannya dan mengambil manfaat untuk kehidupannya yang lebih baik. Maka dari itu pelajaran ekonomi perlu dirancang untuk membangun dan merefleksikan kemampuan siswa dalam kehidupan bermasyarakat yang selalu berkembang secara terus menerus.

Berdasarkan hasil observasi dan pengalaman mengajar di kelas XI IS SMA Negeri 1 Singaraja pada tanggal 24 Juli sampai dengan 12 Agustus 2013 menunjukkan bahwa siswa belum mampu menguasai indikator pelajaran ekonomi secara maksimal. Sehubungan dengan hal tersebut, berdasarkan data hasil nilai evaluasi pada Standar Kompetensi 1 diketahui sebanyak $87 \%$ siswa dari jumlah siswa sebanyak 9 orang belum mampu mencapai angka Kriteria Ketuntasan Minimal (KKM) yang telah ditentukan di sekolah tersebut (Lampiran 2). Nilai yang ditetapkan oleh sekolah siswa yang berhasil mencapai Kriteria Ketuntasan Minimal (KKM) untuk mata pelajaran ekonomi adalah 90. Siswa yang berhasil mencapai KKM hanya 1 orang, dan siswa yang belum berhasil sebanyak 8 orang.

Berdasarkan pengamatan dapat diidentifikasi beberapa permasalahan dalam kegiatan pembelajaran yaitu sebagai berikut: 1) belum terjadinya interaksi antar siswa secara optimal sehingga interaksi hanya terjadi secara dua arah antara guru dan siswa saja, 2) kondisi kelas hanya didominasi oleh beberapa siswa yang memiliki kemampuan yang lebih. Hal tersebut menyebabkan hasil belajar siswa pada mata pelajaran ekonomi belum dapat tercapai secara maksimal.

Dalam proses pembelajaran ada empat komponen penting yang berpengaruh terhadap keberhasilan belajar siswa, yaitu bahan belajar, suasana belajar, media dan sumber belajar, serta guru sebagai subyek pembelajaran (Dimyati, 1994). Sesuai dengan hal tersebut maka dibutuhkan suatu kegiatan yang dilakukan oleh guru dengan upaya meningkatkan hasil belajar siswa.

Pelajaran ekonomi menekankan pada pemberian pengalaman belajar secara langsung melalui penggunaan dan pengembangan keterampilan proses dan sikap sosial. Sikap sosial biasa dikembangkan ketika siswa melakukan diskusi atau kerja kelompok karena pada saat itulah berlangsung kerjasama sehingga diperoleh pengetahuan dan pengalaman yang lebih banyak. Dengan demikian, tugas guru adalah membangkitkan semangat belajar siswa dan meningkatkan partisipasi mereka dengan cara menciptakan suasana belajar yang dinamis, harmonis, menarik dan menciptakan komunikasi dua arah. Guru harus bertindak sebagai fasilitator untuk membentuk dan mengembangkan pengetahuan, bukan untuk memindahkan pengetahuan.

Salah satu model pembelajaran yang dapat mengakomodasi kepentingan untuk mengkolaborasikan pengembangan diri dalam proses pembelajaran adalah model Cooperatif learning. Cooperatif learning berasal dari kata cooperative yang artinya mengerjakan sesuatu secara bersama-sama dengan saling membantu satu sama lainnya sebagai satu kelompok atau satu tim (Isjoni, 2007). Selanjutnya Riyanto (2010) mengemukakan bahwa pembelajaran kooperatif adalah model pembelajaran yang dirancang untuk membelajarkan kecakapan akademik (academic skill), sekaligus keterampilan social (social skill) termasuk interpersonal skill.

Model pembelajaran kooperatif dikembangkan berdasarkan teori Vygotsky, yaitu tentang penekanan pada hakikat sosiokultural dari pembelajaran. Vygotsky menyatakan bahwa fungsi mental yang lebih tinggi pada umumnya muncul dalam percakapan atau kerjasama antar individu sebelum fungsi mental yang lebih tinggi itu diserap kedalam individu tersebut. Implikasi dari teori Vygotsky ini dikehendakinya susunan kelas berbentuk 
pembelajaran kooperatif (Suprijono, 2009). Melalui pembelajaran kooperatif siswa akan dapat melakukan komunikasi sehingga akan terjadi interaksi sosial. Menurut Suprijono (2009: 39), menyatakan bahwa "Keterlibatan dengan orang lain membuka kesempatan bagi peserta didik untuk mengevaluasi dan memperbaiki pemahaman mereka saat mereka bertemu dengan pemikiran orang lain dan saat mereka berpartisipasi dalam pencarian pemahaman bersama". Hal yang sama diungkapkan oleh Isjoni (2012: 13), yang menyatakan bahwa "dengan model kooperatif dapat memotivasi siswa untuk mengemukakan pendapatnya, menghargai pendapat teman, dan saling menghargai pendapat teman (sharing ideas). Oleh karena itu, melalui pembelajaran kooperatif dapat memperbaiki hubungan diantara siswa, mengembangkan keterampilanketerampilan proses kelompok dan pemecahan masalah. Ide penting dalam pembelajaran kooperatif adalah membelajarkan kepada siswa keterampilan bekerjasama dan berkolaborasi. Menurut Trianto (2007) mengemukakan bahwa pembelajaran kooperatif merupakan suatu model pembelajaran yang dibentuk dalam suatu kelompok-kelompok kecil dimana siswa bekerjasama serta mengoptimalkan keterlibatan dirinya dan anggota kelompoknya dalam belajar Keterampilan ini sangat penting bagi siswa, karena pada dunia kerja sebagian besar dilakukan secara berkelompok.

Dengan demikian, tugas guru adalah membangkitkan semangat belajar siswa dan meningkatkan partisipasi mereka dengan cara menciptakan suasana belajar yang dinamis, harmonis, menarik dan menciptakan komunikasi dua arah. Oleh karena itu, apabila guru mengajar tanpa memperhatikan miskonsepsi siswa sebelum materi diajarkan, guru tidak akan berhasil menanamkan konsep yang benar dan hanya sebagian siswa yang mampu memahami materi .

Salah satu model pembelajaran yang dapat diterapkan sebagai alternatif kegiatan pembelajaran untuk mencegah terjadinya kondisi seperti di atas adalah model pembelajaran kooperatif tipe Numbered Head Together (NHT). Numbered head Together (NHT) atau penomoran berpikir bersama adalah merupakan jenis pembelajaran kooperatif yang dirancang untuk memengaruhi pola interaksi siwa dan sebagai alternatif terhadap struktur kelas tradisional (Trianto, 2012). Numbered Head Together (NHT) pertama kali dikembangkan oleh Spenser Kagen (1993) untuk melibatkan lebih banyak siswa dalam menelaah materi yang tercakup dalam suatu pelajaran dan mengecek pemahaman mereka terhadap isi pelajaran tersebut. Dalam teknik ini, guru memperhatikan latar belakang pengalaman siswa dan membantu siswa mengaktifkan skema ini agar bahan pelajaran menjadi lebih bermakna. Selain itu, siswa bekerja sama dengan sesama siswa dalam suasana gotong royong dan mempunyai banyak kesempatan untuk mengolah informasi dan meningkatkan keterampilan berkomunikasi. Numbered Head Together (NHT) sebagai model pembelajaran pada dasarnya merupakan sebuah variasi kelompok. Adapun ciri khas Numbered Head Together (NHT) adalah guru menunjuk siswa untuk mewakili kelompoknya dengan menyebutkan nomor identitas siswa. Menurut Nur (2005), dengan cara tersebut, maka akan terjamin keterlibatan seluruh siswa dan merupakan upaya untuk meningkatkan tanggung jawab individu dalam diskusi kelompok. Selain itu, model pembelajaran Numbered Head Together (NHT) juga memberikan kesempatan kepada siswa untuk membagikan ide-ide dan mempertimbangkan jawaban yang paling tepat (Isjoni, 2010). Sehingga dengan diterapkannya Model pembelajaran ini akan menciptakan lingkungan belajar kooperatif dalam kelompok kecil yang menekankan keterlibatan semua siswa dalam pembelajaran, sehingga akan meningkatkan pemahaman siswa dan hasil belajar siswa lebih bermakna.

Berdasarkan latar belakang di atas, penelitian tindakan kelas ini adalah penerapan model pembelajaran kooperatif tipe Numbered Head Together (NHT) untuk meningkatkan hasil belajar ekonomi siswa kelas XI IS SMA Negeri 1 Singaraja 
pada semester ganjil tahun pelajaran 2013/ 2014.

\section{METODE}

Penelitian ini adalah merupakan Penelitian Tindakan Kelas (PTK). PTK merupakan suatu penelitian bersiklus yang dilakukan oleh guru berdasarkan permasalahan riil yang ditemukan di kelas melalui langkah-langkah merancang, melaksanakan, dan merefleksikan tindakan secara kolaboratif, partisipatif, dan reflektif mandiri dengan tujuan untuk memperbaiki kualitas pembelajaran. Dalam penelitian ini, terdapat kolaborasi atau kerjasama antara guru dan peneliti. Peneliti dan guru menyiapkan instrumen evaluasi/observasi, ikut terlibat dalam pembelajaran dan dalam perencanaan tindakan yang akan dilaksanakan, serta melaksanakan pembelajaran sesuai dengan skenario yang sudah disiapkan bersama.

Dalam penelitian ini menggunakan partisipatif sehingga diharapkan terjadi peningkatan hasil belajar dalam pembelajaran ekonomi. Penelitian ini berbasis kelas yakni tindakan dilakukan pada kelas yang bermasalah yaitu kelas XI IS SMA Negeri 1 Singaraja tahun pelajaran 3013/2014.

Penelitian ini diadakan pada semester ganjil pada tahun ajaran 2013/2014 dan waktunya disesuaikan dengan jadwal pelajaran di sekolah tersebut. Tempat dari penelitian adalah SMA N 1 Singaraja, Kecamatan Buleleng, Kabupaten Buleleng.

Subjek dalam penelitian ini adalah siswa kelas XI IS SMA Negeri 1 Singaraja yang berjumlah 9 orang. Pertimbangan penulis memilih subjek penelitian terhadap siswa kelas XI IS SMA Negeri 1 Singaraja karena kelas ini memiliki masalah dalam hasil belajar ekonomi. Sedangkan objek dari penelitian ini adalah model pembelajaran kooperatif tipe Number Head Together (NHT) dan hasil belajar siswa.

Penelitian ini dilaksanakan dalam pola siklus. Artinya siklus selanjutnya akan ditentukan berdasarkan siklus sebelumnya, sampai diperoleh hasil yang diharapkan. Penelitian ini direncanakan akan dilaksanakan dalam beberapa siklus, tiap siklus akan dilaksanakan sebanyak empat kali pertemuan. Pertemuan pertama, kedua, dan ke tiga untuk pembahasan materi, sedangkan pertemuan ke empat untuk pemberian tes evaluasi dan refleksi. Penelitian tindakan sebagai mana yang dikemukakan oleh Kemmis dan Taggart (dalam Zuriah, 2005) merupakan penelitian yang bersiklus, yang terdiri dari 1) rencana, 2) tindakan, 3) observasi, dan 4) refleksi, yang dilakukan secara berulang. Hal ini dapat digambarkan sebagai berikut.

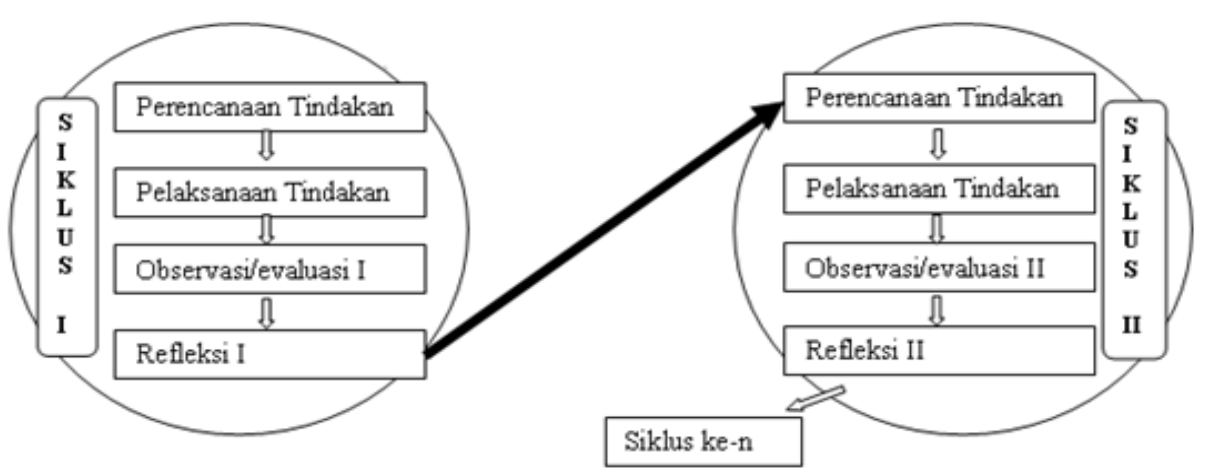

Gambar 1 Model Penelitian Tindakan Kelas

Dimodifikasi dari Kemmis dan Mc. Taggrat (dalam Astawa,2008) 
Pada penelitian tindakan kelas ini, peneliti melakukan pengumpulan data dengan menggunakan teknik tes pilihan ganda. Teknik tes merupakan alat atau prosedur yang sistematis yang terdiri dari seperangkat pertanyaan atau tugas-tugas untuk mengukur prilaku tertentu pada peserta didik dengan menggunakan bantuan skala numeric atau kategori tertentu. Teknik tes ini diharapkan mampu memberikan data hasil belajar siswa pada pelajaran ekonomi. Bentuk tes yang digunakan adalah tes pilihan ganda. Data hasil belajar siswa dikumpulkan dengan metode tes yaitu tes pilihan ganda menyangkut konsep-konsep yang dibahas pada saat pembelajaran.

Teknik analisis data dalam penelitian ini adalah dengan melakukan evaluasi pada akhir siklus. Setelah peneliti memperoleh data hasil belajar, selanjutnya akan dilakukan analisis data. Analisis data menggunakan metode analisis deskriptif kuantitatif. Menurut Agung (2005), analisis deskriptif kuantitatif adalah cara pengolahan data dengan menyusun secara sistematis dalam bentuk angka-angka atau persentase tentang keadaan suatu objek yang diteliti.

\section{HASIL DAN PEMBAHASAN}

Penelitian tindakan kelas ini difokuskan pada model pembelajaran kooperatif tipe Number Head Together (NHT) untuk meningkatkan hasil belajar mata pelajaran ekonomi siswa kelas XI IS SMA $N 1$ Singaraja tahun pelajaran 2013/2014. Penelitian ini dilaksanakan dari tanggal 15 Agustus s/d 14 September 2013 pada siswa kelas XI IS dengan jumlah siswa 9 orang. Penelitian ini dilaksanakan dalam 2 siklus, setiap siklus terdiri dari 5 kali pertemuan, yaitu 4 kali pertemuan untuk melaksanakn tindakan dan yang terakhir untuk tes hasil belajar. Data yang dikumpulkan dalam penelitian ini adalah hasil belajar ekonomi.

Siklus I dilaksanakan pada tanggal 15 Agustus s/d 531 Agustus 2013, dengan menggunakan RPP seperti lampiran 6-9. Berdasarkan refleksi awal, kegiatan yang dilakukan pada tahap perencanaan siklus I meliputi: 1) mensosialisasikan model pembelajaran kooperatif tipe Number Head Together
(NHT) kepada guru pamong sebagai obsever, 2) menyiapakan Rencana Pelaksanaan Pembelajaran (RPP) yang menerapkan model pembelajaran kooperatif tipe Number Head Together (NHT), 3) menyiapkan Lembar Kerja Siswa (LKS), 4) soal-soal tes hasil belajar. Proses pembelajaran diawali dengan kegiatan awal yang berlangsung, menyampaikan apersepsi dengan melakukan tanya jawab kepada siswa dan menyampaikan tujuan pembelajaran yang akan dicapai siswa dalam proses pembelajaran. Pembelajaran dilanjutkan dengan kegiatan inti yang dimulai dengan mengarahkan siswa membaca buku sumber untuk menggali pengetahuan awal siswa, selanjutnya siswa diarahkan untuk mengumpulkan informasi tentang materi yang akan dibahas, kemudian memberikan permasalahan yang akan didiskusikan untuk mengeksplorasi pengetahuan awal siswa. Selanjutnya, guru memberikan orientasi materi pelajaran sesuai dengan model pembelajaran kooperatif tipe Number Head Together.

Tahap selanjutnya, pembentukan kelompok kecil yang beranggotakan 4-5 orang siswa yang memiliki kemampuan akademik heterogen dan perbedaan individu, kemudian membagikan LKS kepada masing-masing siswa dalam kelompok diskusi. Sebelum melakukan diskusi guru menjelaskan langkah-langkah kegiatan diskusi, selanjutnya siswa melakukan diskusi sesuai dengan kelompoknya untuk membahas permasalahan sesuai dengan topik diskusi yang dibagikan. Saat pembelajaran berlangsung, guru dan peneliti bertindak sebagai obsever dan juga sebagai fasilitator dan motivator. Selama kegiatan berlangsung guru memantau aktivitas siswa dan memberikan bimbingan tentang kesulitan yang dihadapi oleh siswa.

Setelah melaksanakan diskusi, siswa diberikan kesempatan untuk menyajikan hasil diskusi kelompoknya. Perwakilan dari tiap-tiap kelompok ditunjuk oleh peneliti secara acak dengan menggunakan nomor identitas sehingga seluruh siswa dituntut kesiapannya untuk menyajikan hasil diskusinya di depan kelas. Saat penyajian hasil diskusi, 
Vol. 2, No. 1, Juni 2014

kelompok lain dapat mengajukan ide atau pendapat, memberikan tanggapan atas pertanyaan temannya, dan bertanya terhadap hasil kerja yang diperoleh kelompok lain. Setelah semua kelompok menyajikan hasil diskusinya, guru menanggapi hasil pekerjaan tiap-tiap kelompok dan memberikan kesempatan kepada siswa untuk bertanya mengenai hal-hal yang belum dimengerti.

Tahap akhir dari proses pembelajaran adalah melakukan refleksi dan evaluasi. Pada tahap refleksi siswa ditanyakan mengenai pendapat dan perasaan setelah mengikuti pembelajaran. Selanjutnya, siswa diberikan kesempatan

\section{Ekuitas-Jurnal Pendidikan Ekonomi}

untuk menyimpulkan materi pembelajaran. Setelah itu, guru memberikan penguatan yang positif berupa pujian dan penghargaan terhadap kegiatan yang telah dilaksanakan. Evaluasi dilaksanakan pada akhir pembelajaran, tujuannya untuk mengetahui pemahaman siswa tentang materi yang telah dibahas. Setelah pelaksanaan evaluasi, guru memberikan tindak lanjut berupa pekerjaan rumah dan sekaligus menutup pelajaran.

Berdasarkan hasil observasi dan evaluasi pelaksanaan tindakan siklus I, maka diperoleh data hasil belajar ekonomi siswa disajikan pada tabel 1 beriku.

Tabel 1 Data Hasil Belajar Siswa pada Siklus I

\begin{tabular}{clccl}
\hline No. & \multicolumn{1}{c}{ Nama Siswa } & $\begin{array}{c}\text { Skor } \\
\text { Perolehan } \\
(\mathrm{X})\end{array}$ & $P=\frac{X}{S M i} \times 100$ & Keterangan \\
\hline 1 & Aprilia Widia Kristianti Ni Made & 10 & 50 & Tidak Tuntas \\
2 & Arjaya Dipariana Yuda Made & 8 & 40 & Tidak Tuntas \\
3 & Ernadi Ni Luh & 14 & 70 & Tidak Tuntas \\
4 & Harisatun Niswa & 19 & 95 & Tuntas \\
5 & Karina Febriyanti Luh Putu & 11 & 55 & Tidak Tuntas \\
6 & Nopi Ariani Ni Made & 12 & 60 & Tidak Tuntas \\
7 & Novi Esa Suryani Putu & 18 & 90 & Tuntas \\
8 & Reni Mariani Kadek & 15 & 50 & Tidak Tuntas \\
9 & Rit Meidyana Ni Made & 18 & 95 & Tuntas \\
& Jumlah Skor Hasil Belajar siswa & 125 & 605 & \\
\hline
\end{tabular}

Data yang tersaji di atas disajikan secara deskriptif kuantitatif dengan menjumlahkan skor yang diperoleh siswa kemudian dibagi dengan skor maksimal ideal. Setelah data tersaji seperti tabel 4.1 di atas, hasil belajar siswa secara individu dijumlahkan sehingga mendapatkan jumlah nilai secara klasikal $(\Sigma x)$ sebesar 605. Selanjutnya, dihitung rata-rata hasil belajar keseluruhan dengan menggunakan rumus sebagai berikut.

$$
\begin{aligned}
M & =\frac{\sum X}{N} \\
& =\frac{605}{9} \\
& =67,22
\end{aligned}
$$

Untuk menentukan tingkat hasil belajar ekonomi siswa dapat dihitung dengan membandingkan rata-rata persen $(\mathrm{M} \%)$ dengan kriteria penilaian acuan patokan PAP sebagai berikut:

$$
\begin{aligned}
& \mathrm{M}(\%)=\left(\frac{\mathrm{M}}{\mathrm{SMI}}\right) \times 100 \% \\
& \mathrm{M}(\%)=\left(\frac{67,22}{100}\right) \times 100 \% \\
& \mathrm{M}(\%)=67,22 \% \\
& \text { Jadi, rata-rata persentase hasil } \\
& \begin{array}{l}
\text { belajar siswa pada siklus I adalah } 67,22 \% \\
\text { dan berada pada kategori cukup saat } \\
\text { dikonversikan ke dalam PAP skala lima } \\
\text { pada tebel 3.2. Hal ini menunjukkan } \\
\text { bahwa hasil belajar siswa secara } \\
\text { keseluruhan belum mencapai target } \\
\text { keberhasilan penelitian tindakan kelas ini }
\end{array}
\end{aligned}
$$


yaitu baru mencapai $67,22 \%$ dan berada pada kategori cukup jika dimasukkan ke dalam PAP skala lima.

Untuk mencari ketuntasan belajar siswa secara klasikal digunakan rumus sebagai berikut.

Ketuntasan klasikal = Banyak siswa tuntas Jumlah siswa (N)

$$
\begin{aligned}
\text { Ketuntasan klasikal } & =\frac{3}{9} \times 100 \% \\
& =33,33 \%
\end{aligned}
$$

Berdasarkan rata-rata persentase hasil belajar siswa di atas, maka diketahui rata-rata persentase hasil belajar siswa $33,33 \%$ pada siklus I. Hal ini menunjukkan bahwa pembelajaran dengan menerapkan model pembelajaran kooperatif tipe Number Head Together (NHT) untuk meningkatkan hasil belajar siswa belum optimal. Setelah diklasifikasikan ke dalam PAP skala lima seperti pada tabel 3.2 rata-rata persentase hasil belajar secara klasikal berada pada kategori cukup sehingga perlu ditingkatkan.

Berdasarkan hasil observasi dan evaluasi selama pemberian tindakan pada siklus I dilakukan refleksi. Hasil refleksi menunjukkan adanya keberhasilan dan beberapa masalah yang menyebabkan hasil belajar ekonomi siswa berada pada kriteria cukup. Temuan-temuan dalam tindakan siklus I menunjukkan beberapa keberhasilan terkait dengan model pembelajaran kooperatif tipe Number Head Together (NHT) diantaranya, dalam kegiatan belajar mengajar siswa sudah mulai aktif dalam proses pembelajaran maupun dalam diskusi kelompok, mendengarkan informasi dan penjelasan guru dengan baik serta mampu mengemukakan, dan dalam kegiatan evaluasi siswa sudah mulai tekun dalam mengerjakan tugas, soal-soal dan menyimpulkan pembelajaran. Namun pada siklus I, belum semua siswa mengalami kemajuan dalam pembelajaran. Beberapa siswa masih belum berani mengajukan pendapat, siswa masih tampak pasif baik dalam proses pembelajaran dan diskusi, serta beberapa siswa ada yang belum berani bertanya dan belum berani menyimpulkan pembelajaran.

Berdasarkan tindakan yang telah dilaksanakan pada siklus I, selanjutnya dilakukan refleksi. Hasil refleksi adalah sebagai berikut.

1) Proses pembelajaran pada siklus I secara umum belum dapat berjalan secara optimal. Hal ini nampak dari siswa yang belum mampu mengikuti proses pembelajaran yang baru mereka masih belum terbiasa untuk mengikuti pembelajaran dengan menggunakan model pembelajaran kooperatif tipe Number Head Together (NHT) .

2) Siswa masih malu-malu untuk mengemukakan pendapat mengenai hal-hal yang belum mereka pahami terkait materi yang diajarkan. Hal ini diketahui dengan mengamati dan menanyakan langsung pada salah satu siswa pada saat proses pembelajaran. Namun setelah diberikan penjelasan siswa kembali aktif dan mau bertanya terkait dengan materi yang belum dimengerti

3) Secara umum siswa belum aktif melakukan diskusi, karena beberapa masih sering bercanda. Setelah diberikan penjelasan mengenai tehnik penilain mereka kemudian mulai aktif dengan kelompoknya.

4) Secara keseluruhan siswa mengalami kesulitan dalam menyimpulkan hasil kerja kelompoknya. Dalam kegiatan tersebut ada beberapa siswa yang sudah mampu memberikan kesimpulan tentang hasil kerja kelompoknya.

5) Pada saat penerapan model pembelajaran kooperatif tipe Number Head Together (NHT) dilaksanakan peneliti masih mengalami kesulitan mengelola waktu pembelajaran agar sesuai dengan waktu yang direncanakan

Bertolak dari kendala-kendala yang dihadapi siklus I peneliti bersama guru mata pelajaran ekonomi bekerjasama untuk mencari alternatif atau solusi, penyelesaian untuk mengatasi permasalahan serta kendala yang muncul pada siklus I kemudian disempurnakan 
pada siklus II. Perbaikan tindakan yang dilakukan sebagai berikut.

1) Memberikan materi diskusi berupa permasalahan terkait dengan masalah yang sedang terjadi terkait dengan materi pelajaran untuk didiskusikan bersama sehingga siswa lebih tertarik dalam kegiatan diskusi.

2) Mengarahkan siswa dalam melakukan kegiatan yaitu dengan membimbing tiap-tiap kelompok secara berulangulang serta lebih memperhatikan mereka dalam melakukan kegiatan pembelajaran.

3) Menugaskan siswa untuk membaca terlebih dahulu materi di rumah untuk kegiatan pembelajaran selanjutnya tujuannya agar siswa lebih memahami materi yang akan dibahas pada pertemuan selanjutnya.

4) Menjelaskan kembali kepada siswa bahwa sikap mereka dalam mengikuti proses pembelajaran berlangsung akan diamati dan dinilai.

5) Memberikan pertanyaan khusus terkait materi yang didiskusikan jika ada siswa yang tidak melakukan diskusi dengan temannya.

6) Memberikan contoh-contoh nyata yang berkaitan dengan kehidupan seharihari siswa dalam proses pembelajaran agar lebih menarik dan siswa lebih paham terhadap materi yang diajarkan.

7) Peneliti akan mengelola waktu lebih efektif dengan melakukan perbaikanperbaikan pada proses pembelajaran yang masih kurang dalam mengalokasikan waktu pembelajaran

Siklus II dilaksanakan pada tanggal 4 September s/d 14 September 2013, dengan menggunakan RPP seperti Lampiran 13-15. Berdasarkan refleksi siklus I, kegiatan yang dilakukan pada tahap perencanaan siklus II meliputi: 1) Melakukan diskusi dengan guru pamong tentang tindakan yang akan dilakukan untuk memperbaiki permasalahan yang ditemui pada siklus I, 2) Menyiapkan Rencana pelaksanaan pembelajaran (RPP) yang menerapkan model pembelajaran kooperatif tipe Number Head Together (NHT), 3) Menyiapkan Lembar Kerja Siswa (LKS), 4) membuat soal-soal tes hasil belajar. Pembelajaran dimulai dengan kegiatan awal, yaitu melakukan koordinasi kelas, mempersiapkan siswa secara psikis dan fisik untuk mengikuti pembelajaran, memotivasi siswa untuk mengikuti pembelajaran dengan antusias, lebih menekankan proses pembelajaran tentang materi APBN dan APBD, mengarahkan perhatian siswa kepada sasaran yang diharapkan (apersepsi), dan menjelaskan tujuan dan langkah pembelajaran. Pembelajaran dilanjutkan dengan kegiatan inti yang dimulai dengan mengajak siswa untuk mengamati lingkungan sekolah untuk mencari informasi tentang kegiatan organisasi, mengarahkan siswa membaca buku sumber untuk menggali pengetahuan awal siswa, kemudian siswa diajak untuk tanya jawab mengenai hasil pengamatan yang telah dilakukan. Selanjutnya, guru memberikan orientasi materi pelajaran sesuai dengan model pembelajaran kooperatif tipe Number Head Together (NHT).

Tahap selanjutnya, siswa dibagi menjadi beberapa kelompok yang beranggotakan 4-5 orang siswa yang memiliki kemampuan akademik heterogen dan perbedaan individu, kemudian membagikan LKS kepada masing-masing kelompok diskusi. Sebelum melakukan diskusi guru menjelaskan langkah-langkah kegiatan diskusi, selanjutnya siswa melakukan diskusi sesuai dengan kelompoknya untuk menjawab LKS yang dibagikan. Saat pembelajaran berlangsung, guru dan peneliti bertindak sebagai obsever dan juga sebagai fasilitator dan motivator. Selama kegiatan berlangsung guru memantau aktivitas siswa dan memberikan bimbingan tentang kesulitan yang dihadapi oleh siswa.

Dari kegiatan diskusi yang telah dilakukan oleh tiap kelompok, perwakilan setiap kelompok menyajikan hasil diskusi kelompoknya ke depan kelas secara acak dengan menggunakan nomor identitas yang dipanggil guru. Saat diskusi berlangsung, kelompok lain dapat memberikan tanggapan dan pertanyaan atas diskusi yang telah dilakukan. Pada pertemuan ini siswa sudah ada yang berani betanya tentang materi yang belum dipahami. Hal ini dapat disambut baik oleh peneliti, tetapi peneliti tidak menjawab 


\section{Vol. 2, No. 1, Juni 2014}

secara langsung melainkan meminta teman lain atau dari kelompok lain untuk memberi pendapat. Melalui tanya jawab yang dilakukan peneliti dan siswa, secara tidak langsung peneliti dan siswa menyimpulkan hasil diskusi yang dilakukan.

Melalui pengamatan, peneliti menilai siswa yang aktif menjawab dengan tetap memperhatikan ketepatan jawaban yang disampaikan siswa, sehingga pembelajaran menjadi lebih efektif dan siswa menjadi lebih antusias untuk mengikuti proses pembelajaran. Setelah semua kelompok menyajikan hasil diskusinya, guru menanggapi hasil pekerjaan tiap-tiap kelompok dan memberikan kesempatan kepada siswa untuk bertanya mengenai hal-hal yang belum dimengerti.

\section{Ekuitas-Jurnal Pendidikan Ekonomi}

Tahap akhir dari proses pembelajaran adalah melakukan refleksi dan evaluasi. Siswa diberikan kesempatan untuk menyimpulkan materi pembelajaran. Setelah itu, guru memberikan penguatan yang positif berupa pujian dan penghargaan terhadap kegiatan yang telah dilaksanakan. Selanjutnya diberikan tes evaluasi, untuk mengetahui pemahaman siswa tentang materi pembelajaran, setelah tes evaluasi, peneliti memberikan tindak lanjut berupa pekerjaan rumah (PR) dan sekaligus menutup pelajaran.

Berdasarkan hasil observasi dan evaluasi pelaksanaan tindakan siklus II, maka diperoleh data hasil belajar ekonomi siswa disajikan pada tabel 2 berikut.

Tabel 2 Data Hasil Belajar Siswa Pada Siklus II

\begin{tabular}{clccc}
\hline No. & \multicolumn{1}{c}{ Nama Siswa } & $\begin{array}{c}\text { Skor } \\
\text { Perolehan } \\
(\mathrm{X})\end{array}$ & $P=\frac{X}{S M i} \times 100$ & Keterangan \\
\hline 1 & Aprilia Widia Kristianti Ni Made & 27 & 90 & Tuntas \\
2 & Arjaya Dipariana Yuda Made & 22 & 73 & Tidak Tuntas \\
3 & Ernadi Ni Luh & 28 & 93 & Tuntas \\
4 & Harisatun Niswa & 27 & 90 & Tuntas \\
5 & Karina Febriyanti Luh Putu & 27 & 90 & Tuntas \\
6 & Nopi Ariani Ni Made & 28 & 93 & Tuntas \\
7 & Novi Esa Suryani Putu & 30 & 100 & Tuntas \\
8 & Reni Mariani Kadek & 27 & 90 & Tuntas \\
9 & Rit Meidyana Ni Made & 28 & 93 & Tuntas \\
& Jumlah Skor Hasil Belajar siswa & 244 & 812 & \\
\hline
\end{tabular}

Data yang tersaji di atas disajikan secara deskriptif kuantitatif dengan menjumlahkan skor yang diperoleh siswa kemudian dibagi dengan skor maksimal ideal. Setelah data tersaji seperti tabel 4.2 hasil belajar siswa secara individu dijumlahkan sehingga mendapatkan jumlah nilai secara klasikal $(\Sigma x)$ sebesar 812. Selanjutnya dihitung rata-rata hasil belajar keseluruhan dengan menggunakan rumus sebagai berikut.

$$
\begin{aligned}
M & =\frac{\sum X}{N} \quad=\frac{812}{9} \\
& =90,22
\end{aligned}
$$

Nilai rata-rata di atas kemudian dikonversikan ke dalam PAP skala lima. Untuk mengkonversikan ke dalam PAP terlebih dahulu dicari rata-rata presentase keseluruhan. Rata-rata presentase dihitung dengan menggunakan rumus sebagai berikut.

$$
\begin{aligned}
& \mathrm{M}(\%)=\left(\frac{\mathrm{M}}{\mathrm{SMI}}\right) \times 100 \% \\
& \mathrm{M}(\%)=\left(\frac{90,22}{100}\right) \times 100 \% \\
& \mathrm{M}(\%)=90,22 \%
\end{aligned}
$$


Jadi, rata-rata presentase hasil belajar siswa pada siklus II adalah 90,22\% dan berada pada kategori sangat baik saat dikonversikan ke dalam PAP skala lima pada tabel 3.2. Hal ini menunjukkan bahwa hasil belajar siswa secara keseluruhan sudah mencapai target keberhasilan penelitian tindakan kelas ini yaitu mencapai $90,22 \%$ dan berada pada kategori sangat baik jika dimasukkan ke dalam PAP skala lima.

Untuk mencari ketuntasan belajar siswa secara klasikal digunakan rumus sebagai berikut.

$$
\begin{aligned}
\text { Ketuntasan klasikal }= & \frac{\text { Jumlah siswa tuntas } x}{\text { Jumlah siswa }(N)} \\
\text { Ketuntasan klasikal } & =\frac{8}{9} \times 100 \% \\
& =89 \%
\end{aligned}
$$

Berdasarkan rata-rata persentase hasil belajar siswa di atas, maka diketahui rata-rata persentase hasil belajar siswa $90,22 \%$ pada siklus II. Hal ini menunjukkan bahwa pembelajaran dengan menerapkan model pembelajaran kooperatif tipe Number Head Together (NHT) dalam upaya meningkatkan hasil belajar siswa sudah mencapai target. Setelah diklasifikasikan ke dalam PAP skala lima pada table 3.2 rata-rata persentase hasil belajar secara klasikal berada pada kategori sangat baik. Berdasarkan rincian tersebut maka dapat disimpulkan pencapaian persentase hasil belajar pada siklus II sudah mencapai target yang telah ditetapkan.

Pelaksanaan tindakan pada siklus II merupakan pengoptimalan dan antisipasi kendala yang muncul pada siklus I. Berdasarkan tindakan siklus II hasil belajar yang diperlihatkan pada siklus II juga mengalami peningkatan. Hal ini terbukti dari hasil yang ditunjukkan setelah pelaksanaan siklus II yaitu persentase tingkat hasil belajar sebesar $90,22 \%$.

Berdasarkan tindakan yang telah dilaksanakan pada siklus II, selanjutnya dilakukan refleksi. Hasil refleksi adalah sebagai berikut.
1) Secara umum proses pembelajaran siswa telah dapat berjalan sesuai dengan rancangan pembelajaran yang direncanakan sehingga hasil belajar yang diharapkan dapat tercapai. Kondisi pembelajaran pada siklus II tampak lebih kondusif, dimana siswa dapat beradaptasi dengan proses pembelajaran dengan menerapkan langkah-langkah dengan model pembelajaran kooperatif tipe Number Head Together (NHT).

2) Siswa sudah tidak malu-malu untuk mengungkapkan pendapat dan bertanya jika tidak mengerti selama proses pembelajaran.

3) Dalam kegiatan diskusi siswa sudah aktif mendiskusikan permasalahan yang mereka peroleh dengan anggota kelompoknya, selain itu dalam membuat kesimpulan jawaban sudah pada kesimpulan materi yang diharapakan

4) Telah terjadi peningkatan rata-rata persentase hasil belajar ekonomi dari siklus I ke siklus II sebesar 23\% ini menandakan bahwa penerapan model kooperatif tipe Number Head Together(NHT) dapat meningkatkan hasil belajar ekonomi.

Walaupun secara umum proses pembelajaran dengan penerapan model pembelajaran kooperatif tipe Number Head Together (NHT) sudah berjalan dengan baik namun masih terdapat sedikit kendala seperti siswa masih senang bermain yang mengakibatkan suasana kelas menjadi sedikit ribut, percecokan antar anggota kelompok yang tidak sependapat masih terjadi dan ada beberapa siswa yang kurang mampu dalam proses pembelajaran. Oleh karena hasil belajar ekonomi siswa sudah mencapai KKM dan ketuntasan belajar siswa sudah mencapai kriteria yang ditetapkan, maka penelitian tidak dilanjutkan dan penelitian dihentikan.

\section{SIMPULAN DAN SARAN}

Berdasarkan permasalahan yang dirumuskan dan hasil dari analisis data, maka dapat disimpulkan bahwa penerapan model pembelajaran kooperatif tipe Number Head Together (NHT) dapat meningkatkan hasil belajar ekonomi siswa 


\section{Vol. 2, No. 1, Juni 2014}

kelas XI IS SMA N 1 Singaraja pada semester ganjil tahun pelajaran 2013/2014. Hal ini dapat dilihat dari nilai rata-rata hasil belajar ekonomi yaitu Pada siklus I ketuntasan belajar siswa hanya mencapai $33,33 \%$ dengan rata-rata hasil belajar siswa sebesar 67,22, sedangkan pada siklus II ketuntasan belajar siswa sudah mencapai $91,70 \%$ rata-rata hasil belajar siswa sebesar 90,22. Dari siklus I hingga siklus II ketuntasan belajar siswa mengalami peningkatan sebesar $58,37 \%$.

Saran yang dapat disampaikan sehubungan dengan hasil penelitian ini adalah sebagai berikut.

1) Bagi sekolah, penelitian ini agar dijadikan sebagai pedoman dalam pembelajaran ekonomi dan juga pembelajaran ilmu-ilmu lain guna meningkatkan hasil belajar siswa.

2) Bagi guru, diharapkan agar guru ekonomi dapat menerapkan model pembelajaran kooperatif tipe Number Head Together (NHT) dalam pembelajaran sebagai suatu alternatif dalam inovasi pembelajaran. Hal ini ini perlu dilakukan karena penerapan model pembelajaran kooperatif tipe Number Head Together (NHT) dapat meningkatkan hasil belajar ekonomi siswa.

3) Bagi siswa, diharapkan kepada siswa kelas XI IS SMA N 1 Singaraja agar pada saat mengikuti pelajaran ekonomi dengan diterapkannya model pembelajaran kooperatif tipe Number Head Together (NHT) agar menyiapkan diri baik secara fisik maupun mental sehingga pembelajaran di kelas dapat berlangsung optimal yang nantinya akan dapat meningkatkan hasil belajar siswa.

4) Bagi peneliti, dengan menggunakan model pembelajaran kooperatif tipe Number Head Together (NHT) dalam melakukan suatu penelitian dapat dijadikan suatu pengalaman sebagai calon guru profesional untuk mengatasi permasalahan-permasalahan yang terjadi di kelas. Untuk selanjutnya, dalam melaksanakan pembelajaran di kelas tidak hanya menggunakan model pembelajaran kooperatif tipe Number Head Together (NHT) saja, tetapi juga dapat menerapkan model

\section{Ekuitas-Jurnal Pendidikan Ekonomi}

pembelajaran lain yang cocok sesuai dengan karakteristik siswa dan materi yang akan dibahasa dalam kegitan pembelajaran.

\section{DAFTAR PUSTAKA}

Agung, A. A. Gede, 1997. Pengantar Evaluasi Pengajaran, Singaraja: STKIP.1999. Metodologi Penelitian Pendidikan, Singaraja: STKIP Singaraja.

Isjoni, 2010. Cooperatf Learning Efektivitas Pembelajaran Kelompok. Bandung: Alfabeta.

Dimyati. 1994. Belajar dan Pembelajaran. Jakarta: Rineka Cipta

Dimyati dan Moedjono, 1992. Strategi Belajar Mengajar. Jakarta: Depdikbud

Suprijono. 2009. Cooperatif Learning Teori dan Aplikasi Paikem. Yogyakarta: Pustaka Pelajar.

Suprijono. 2010. Cooperatif Learning. Surabaya: Pustaka Belajar

Trianto. 2010. Model-Model Pembelajaran Inovatif Berorientasi Kontruktivistik. Jakarta: Prestasi Pustaka.

Trianto. 2012. Mendesain Model Pembelajaran Inovatif- Progresif. Jakarta: Kencana. 